\title{
PUBLISHED LETTER
}

\section{Citation*}

Aerts R 2013. Old trees: extraction, conservation can coexist. Science 339, 904-904.

DOI: $10.1126 /$ science.339.6122.904-a

* For research papers for which authors are required by their funding agencies to make research results publicly available, the accepted version of the manuscript after peer review (not the final published version after editing and production) may be posted to the funding body's archive or designated repository (such as PubMed Central) six months after publication in Science.

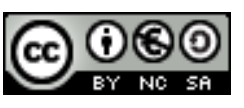

Creative Commons Attribution-Noncommercial-Share Alike 2.0 Belgium License 
Because large old trees are essential for forest ecosystem integrity and biodiversity, timber extraction in managed forests should preferentially be concentrated where large old trees are least likely to develop ("Global decline in large old trees," D. B. Lindenmayer $e t$ al., Perspectives, 7 December 2012, p. 1305). However, timber extraction and the conservation of large old trees are not necessarily mutually exclusive.

Current forest policy and management practices in Flanders, Belgium aim to convert even-aged stands (areas in which trees are all the same age) to stands with trees of varying ages, in an effort to increase forest ecosystem stability and resilience and to allow trees to grow old. As part of their ecologically sustainable forest management, public forest managers have adopted a large-tree retention approach [see also $(1,2)]$. Tree islands within stands managed for production of high-quality timber are reserved for conservation, and trees within these islands will never be extracted. Large old trees of commercially valuable species that have grown beyond the commercially optimal dimensions will not be logged either. And no tree beyond a threshold diameter [currently set at dbh (diameter at breast height) of more than $102 \mathrm{~cm}$ ] will ever be logged. The strip-shelterwood system (in which trees are cut in linear rows, and surrounding trees are given time to grow old) and the coppice-with-standards system (in which some trees are left to grow while others around them are cut) are two examples of forest management that allows the combination of sustainable forest exploitation and conservation of large old trees.

Division Forest, Nature and Landscape, University of Leuven, Celestijnenlaan 200E-2411, BE-3001 Leuven, Belgium. E-mail: raf.aerts@ biw.kuleuven.be

RAF AERTS

References

1. D. B. Lindenmayer, W. F. Laurance, Biol. Conserv. 151, 11 (2012).

2. D. B. Lindenmayer et al., Conserv. Lett. 5, 421 (2012). 